6. Teachers who send in entries om their pupils also qualify for a rize. One teacher will be chosen

PRIZES: Prizes will be donated by the Saskatchewan Natural History Society. Three izes will be awarded to student entries each issue, provided they are of prize-winning standard. he prize-winners are to select their prize from the following list of books: The Peterson Field uider series (birds, butterflies, mammals. rocks arit minerals, trees and shrubs, amphibians and ptiles, ferns, animal tracks), Budd's Wild Plants of the Canadian Prairies, Photography for enagers, or a year's subscription to Canadian Nature.

\title{
Observations at a Beaver Dam
}

By MARGARET SCHICK, age 13, Lorlie, Sask.

One warm June afternoon our class ent out on a nature hike to the earby Pheasant Creek. We were to ook for examples of mammals, reples, insects and other wildlife subects. On a roadside slough we saw ach ducks as the Blue-winged Teal, Pintail and Scaups all in neighourly company. Gulls darted nervusly over a weedy slough. A Iourning Dove cood plaintively as e neared its home.

We finally arrived at the beaver am. The beavers use mud and sticks build it so strong that a person an walk over it. A good reservoir water is held back to provide xcellent habitat for many birds and nimals. Large trees have been cut own, some quite recently to provide heir food. Unlike the rabbit who hews the bark off in a ring and aves the tree to die, the beaver ses the whole tree, cutting it into norter lengths to store away for later se. There was a small shallow overow pool where the little fish were unning themselves on the rocks. We aught snails, bloodsuckers, a baby sh and other things. The Blue leron rose slowly into the air with

\section{More Squirrel Comments}

y Kathy Skinner, age 14 Indian Head, Sask.

(see Kathy's story in the Blue Jay, March, 1957)

My family and I were very intersted in your note, after my story. in interesting fact is that there were quirrels in this valley in 1882 . When hy grandfather settled here, there vere so many that they were considred pests, for they chewed the grainacks and binder canvases to line heir nests. long legs stretched out behind him. We heard a Red-winged Blackbird whistling from the top of a high tree. There was a catbird, canary and kingbird singing. In the distance we could hear a noise like a far away tractor starting up. We came to the conclusion that it was a prairie chicken drumming on his hollow log. Further up the creek we saw another dam. Along the water's edge we found many strange water plants. Two snakes slid away in the grass.

About three o'clock we climbed a hill with our crayons and paper under cur arms. In the next half hour we made an outline sketch of the scenery. It was hard to put the wonders of nature on paper. We were all sorry to leave for the school but we had enjoyed a full afternoon of nature.

NOTE: The "Canary" which Margaret refers to is more properly called a Goldfinch. Canaries are not native to this province. The "Prairie Chicken" drumming on a hollow log is more than likely a Ruffed Grouse so called because of the black feathers on either side of its breast which it spreads out when performing its mating dance. The true "Prairie Chicken" is extremely rare if not completely non-existent in this province.

In the coulees during the winter, we often see mushrooms up in tree crotches, where the squirrels have stored them! Our squirrel is seen eating maple and ash seeds quite often. This time of year they eat buds and lick the sap off the bark.

Our little friend Squikker, whom I wrote about, is a female. We thought she was a he! Lately she has lost the bright red color of her coat, and it has become rather dull and shabby. The other day we noticed that there were six little buttons on her vest! Six little babies! We really hope that she brings them down to visit us later on! 